\title{
CHEMOPROTECTIVE EFFECT OF EDIBLE GASTROPOD, XANCUS PYRUM AND ITS USEFULNESS IN THE AMELIORATION OF CISPLATIN-INDUCED TOXICITY
}

\author{
BINDHU JAYAPRAKASH ${ }^{1 *}$, EMILIN RENITTA ${ }^{2}$ \\ ${ }^{1}$ Department of Biotechnology, Bannari Amman Institute of Technology, Sathyamangalam - 638 401, Erode, Tamil Nadu, India. \\ ${ }^{2}$ Department of Biotechnology, Karunya University, Coimbatore - 641 114, Tamil Nadu, India. Email: bindhu@bitsathy.ac.in
}

Received: 02 August 2017, Revised and Accepted: 05 September 2017

\section{ABSTRACT}

Objective: The main purpose of this study was to evaluate chemoprotective activities of methanolic extracts of an edible gastropod (Xancus pyrum) in cisplatin-induced immunosuppressed mice.

Methods: Cisplatin (100 mg/kg, intraperitoneally [IP]) induced immunosuppressed mice were treated with a methanolic extract of X. pyrum $(0.5 \mathrm{mg} /$ dose/animal/IP) for a period of 10 days. The effect of the extract on lymphoid organ weight, bone marrow cellularity (BMC), alpha esterase activity, and on enzyme levels such as serum glutamic oxaloacetic transaminase, serum glutamic pyruvic transaminase, urea, and creatinine was estimated to identify the chemoprotective activity of $X$. pyrum.

Results: Administration of $X$. pyrum extract in cisplatin-treated mice, found to enhance the BMC and alpha-esterase positive cells, which were drastically reduced in cisplatin alone treated control animals suggests that cisplatin-induced myelosuppression was reversed or inhibited by $X$. pyrum extract administration possibly through its chemoprotective activity.

Conclusion: Cisplatin and its metabolites can bind to DNA, causing damage that may result in chromosome breaks, micronucleus formation and cell death. Administration of X. pyrum extract in cisplatin-treated mice, found to enhance the BMC and alpha-esterase positive cells, which were drastically reduced in cisplatin alone treated control animals suggests that cisplatin-induced myelosuppression was reversed or inhibited by $X$. pyrum extract administration possibly through its chemoprotective activity.

Keywords: Gastropod, Xancus pyrum, Chemoprotective, Cisplatin, Alpha esterase.

(c) 2017 The Authors. Published by Innovare Academic Sciences Pvt Ltd. This is an open access article under the CC BY license (http://creativecommons. org/licenses/by/4. 0/) DOI: http://dx.doi.org/10.22159/ajpcr.2017.v10i12.21762

\section{INTRODUCTION}

Cancer is caused by both external factors (tobacco, chemicals, radiation, and infectious organisms) and internal factors (inherited mutations, hormones, immune conditions, and mutations that occur from metabolism). These casual factors may act together in sequence to initiate or promote carcinogenesis [1]. This is the single largest group of human cancers forming about $80 \%$ of all cancers [2]. Cancer is treated with surgery, radiation, chemotherapy, hormone therapy, biological therapy, and targeted therapy. Radiotherapy and chemotherapy remain the dominant weapons in the arsenal for the treatment of cancer. They kill not only the tumor cells but also normal cells [3]. An ideal strategy would be to identify anticancer agents that trigger effectively the process of cell death preferentially in tumor cells [4]. This can also produce diarrhea or constipation, malnutrition, and dehydration. This can result in rapid weight loss. Hair loss, some medications that kill rapidly dividing cells cause dramatic hair loss; other medications may cause hair to thin. These are temporary effects: Hair usually starts growing back a few weeks after the last treatment, sometimes with a tendency to curl that may be called a "chemo perm" [5].

It has been reported that $1 / 3^{\text {rd }}$ of cancer patients use some form of complementary and other alternative medicines. In the recent times, considerable attention has been focused on the identification and development of natural products for chemoprevention by systemic and rigorous screening processes many of the potential chemopreventive agents have shown considerable safety and efficacy in the preclinical evaluation and are in the stages of clinical testing [6]. The gastropods include many thousands of species of marine snails and sea slugs, as well as freshwater snails and freshwater limpets, and the terrestrial (land) snails and slugs [7]. In recent years of novel metabolites with potent pharmacological properties have been discovered from a marine organism. One among them is gastropod which includes gastropod Xancus pyrum [8]. Of the 14 fatty acids methyl esters investigated 8 were saturated fatty acids and 6 unsaturated fatty acids. Whereas out of 8 saturated fatty acids, 5 of them were the common acids. These fatty acids were used to treat cardiac diseases and obesity $[9,10]$.

The heritability of cancers is usually affected by complex interactions between carcinogens and the host's genome [11]. The key structure of carotenoids for the expression of antiobesity effect was suggested to be the carotenoid end of the polyene chromophore containing an allenic bond and two hydroxyl groups [12]. Other cancer-promoting genetic abnormalities may be randomly acquired through errors in DNA replication, or are inherited [13], radiotherapy and chemotherapy can affect some healthy, fast-growing cells causing side effects such as diarrhea, nausea, hair loss, and fatigue [14]. Epidemiological evidence indicates several factors likely to have a major effect on reducing rates of cancer such as reduction of smoking, increased consumption of fruits and vegetables, and control of infections. Other factors are avoidance of intense sun exposure, increase in physical activity, and reduction of alcohol consumption [15]. In recent times, focus on plant research has been intensified all over the world and a large amount of evidence has been collected to show immense potential of medicinal plants used in various conventional systems [16]. One of their main strategies is to increase body's natural resistance to disease-causing agent itself in practice [17]. Due to deadly nature of cancer, the FDA has allowed drugs that are less than completely specific to be approved. Despite the potential for side effects, these drugs are considered the most successful means by which to treat cancer [18]. The history of natural products as anticancer compounds began in 1947 with augertoxin being isolated 
from Terebra subulata [19]. This extract increased the circulating antibody titer in experimental animals [20]. Analysis of serum from gastropod Concholepas concholepas treated mice showed an increased interferon- $\gamma$ and low interleukin-4, which correlated with antibody isotopes, confirming that hemocyanins induce a Thelper Type 1 cytokine profile [21]. The structural diversity of these resources allows to find new molecules which may be active in many clinical situations [22]. Administration of terpenoids increased the total antibody production, antibody-producing cells in spleen, bone marrow cellularity (BMC), and alpha-esterase positive cells when significantly compared to the normal animals indicating its potentiating effect on the immune system [23]. Chemoprevention is the name coined by Michael Sporn in the 1970s, is an attempt to utilize non-toxic chemical substances or their mixtures to interfere with neoplastic development [24]. Chemotherapy, being a major treatment modality used for the control of advanced stages of malignancies and as a prophylactic against possible metastasis, exhibits severe toxicity on normal tissues [25]. When chemotherapeutic drugs interfere with the division of cancer cells, they also interfere with the division of normal cells. Adverse reactions usually affect cells of the body that have a rapid turnover such as blood cells of the gastrointestinal tract, and it causes side effects [26].

It is experimentally proved that the deep-sea collection and aquaculture added to the growing recognition of the tremendous biodiversity present in the marine world, and has contributed to the growing interest of exploring the oceans as a potential source of new anticancer candidates. This is reflected in the number of marine-derived compounds undergoing preclinical and early clinical development [27]. Hemocyte, the chief immunoreactivity blood cell of a gastropod is capable of eliciting cell-mediated immune reaction by various means [28].

The highly sensitive radioimmunoassay will be useful for pharmacokinetic studies in conjunction with the planned Phase I clinical trials of this novel, extremely potent, tubulin binding agents, of which dolastatin 10 from gastropod appears to possess the more promising preclinical features [29]. These findings might support and/or hypothesize about the origin and diversification of the vertebrate molecules from its ancestral form(s) from the invertebrates, and basic physiological functions of these ancestral biomolecules including some of the cellular structures plausibly remain the same regardless their structural changes even after evolution [30-32].

$X$. pyrum Linnaeus (Xancidae and Gastropoda) vernacular name Shankh shell, the slow-moving animal. The marine oils present unusual difficulties in the analysis because of the wide variety of unsaturated fatty acids [8]. Whereas ordinary oils may generally be analyzed in terms of individual acids, in case of marine oils, it is only possible to estimate the various acids according to chain length. The fatty acids from the gastropod X. pyrum were obtained through extraction, isolation and chromatographic separation of visceral mass of the animals [8-10].

\section{Systematic position \\ - Kingdom: Animalia \\ - Phylum: Mollusca \\ - Class: Gastropoda \\ - Clade: Neogastropoda \\ - Superfamily: Muricoidea \\ - Family: Turbinellidae \\ - Subfamily: Turbinellinae \\ - Genus: Xancus \\ - Species: X. pyrum.}

\section{METHODS}

\section{Animals}

Inbred BALB/C (6-8 weeks) mice, weighing 23-28 g, were obtained from Pasteur Institute, Breeding Section, Coonoor. The animals were housed in ventilated plastic cages at $37 \pm 1^{\circ} \mathrm{C}, 40 \pm 10 \%$ humidity, and $12 / 12$-hrs light/dark cycles during 2 weeks of acclimatization to laboratory conditions and throughout the entire experimental period. The animals were fed with normal mouse chow (Sai Feeds, Mumbai, India) and given water ad libitum. All animal experiments were conducted according to the rules and regulations of Animal Ethics Committee, Government of India.

\section{Preparation and administration of extract}

X. pyrum (Gastropod) was collected from shell meat dealers, Tutucorin, Southeast coast of India. The gastropod meat was washed in distilled water and dried in a hot air oven at $50^{\circ} \mathrm{C}$. The dried meat was powdered and extracted overnight by stirring with 10 volumes of $75 \%$ methanol. Supernatant was collected after centrifuging at $3000 \mathrm{rpm}$ for 10 minutes. The solvent was evaporated to dryness at $45^{\circ} \mathrm{C}$ in hot water bath. The yield of the extract was $10 \%$. For animal administration, the extract was dissolved in minimum quantity of methanol, then resuspended in 1\% gum acacia in phosphate buffered saline (PBS) and given at a concentration of $0.5 \mathrm{~g} / \mathrm{dose} /$ animal/intraperitoneally (IP). For in vitro experiments, the extract was dissolved in dimethyl sulfoxide (DMSO) and diluted in the medium so that the concentration of DMSO was $<0.1 \% \mathrm{vol} / \mathrm{vol}$.

\section{Experimental protocol}

The animals were divided into three groups of six animals each as follows:

- Group 1: Normal animals, without any treatment

- Group 2: Treated animals received cisplatin alone dissolved in $1 \%$ gum acacia IP for 10 consecutive days

- Group 3: Treated animals received X. pyrum $(0.5 \mathrm{mg})$ methanolic extracts dissolved in $1 \%$ gum acacia IP for 10 consecutive days.

Determination of the effects of on $X$. pyrum on lymphoid organ weight in cisplatin-treated animals

Eighteen animals were randomly divided into three groups containing six animals each, one as normal, which did not receive any treatment. The second group of treated animals, treated with cisplatin alone. Third group treated with cisplatin and X. pyrum. Three animals from each group were sacrificed at two different time intervals $\left(7^{\text {th }}\right.$ and $11^{\text {th }}$ day) by cervical dislocation. Body weight of each animal was taken before sacrifice; lymphoid organs such as thymus and spleen were excised, weighed and expressed as relative organ weight.

Determination of the effects of $X$. pyrum on BMC in cisplatintreated animals

BMC was done according to the method of Sredni et al. (1992). Bone marrow was collected from the femur into the medium containing $2 \%$ serum and made into single cell suspension. The number of cells was determined using a hemocytometer and expressed as total cells determined by trypan blue (1\% in saline) exclusion method prefemur [33].

Determination of the effects of $X$. pyrum on alpha esterase activity in cisplatin-treated animals (azo dye coupling method, Bancroft and Cook, 1984)

Esterase enzyme present or absent in monocytes hydrolyses the substrate alpha-naphthyl acetate to form an invisible primary reaction product. The complex is coupled with the diazonium salt to produce colored final reaction product under the microscope [34]. Bone marrow from both femurs of mice was collected in PBS, washed thrice and smeared over the slides. Air-dried slides were fixed in freshly prepared fixative 30 seconds at $4{ }^{\circ} \mathrm{C}$ and dipped in double distilled water thrice. Air-dried slides were incubated at room temperature in the following freshly prepared filtered solution. $1.2 \mathrm{ml}$ solution A and $1.2 \mathrm{ml}$ solution B were mixed well and allowed to react for 1 minute after which solution $\mathrm{C}$ was added and was made up to $50 \mathrm{ml}$ solution by phosphate buffer (pH 7.4).

Slides were incubated in above solution for 45 minutes at $37^{\circ} \mathrm{C}$. After incubation slides were washed in double distilled water for 10 minutes and counter stained with hematoxylin for 1 minute. After staining, slides 
were washed in water for a long time and observed under a microscope $(\times 100$, oil immersion) for scoring positive and negative alpha esterase cells out of 4000 cells.

Determination of the effect of $X$. pyrum on enzyme levels in cisplatin-treated animals

Liver homogenates were made in ice cold Tris buffer $(0.1 \mathrm{M} \mathrm{pH} 7.4)$ and were used for the estimation of serum glutamic oxaloacetic transaminase (SGOT), serum glutamic pyruvic transaminase (SGPT), urea, and creatinine. Serum was also used to estimate all the above parameters.

Estimation of SGPT and SGOT (Span Diagnostics Ltd., Surat, India) Alanine aminotransferase (ALT) catalyzes the transamination of L-alanine and $\alpha$-ketoglutarate to form pyruvate and L-glutamate. Pyruvate so formed is coupled with 2,4-dinitrophenyl hydrazine (2,4-DNPH) to form a corresponding hydrazone, a brown colored complex in alkaline medium and this can be measured colorimetrically [35]. Aspartate aminotransferase (AST) catalyzes the transamination of L-aspartate and $\alpha$-ketoglutarate to form L-glutamate and oxaloacetate. Oxaloacetate so formed is coupled with 2,4-DNPH to form a corresponding hydrazone, a brown colored complex in alkaline medium and this can be measured colorimetrically [35]

Estimation of urea and creatinine (Span Diagnostics Ltd., Surat, India)

Urea is converted quantitatively to ammonia and $\mathrm{CO}_{2}$ in the presence of urease. The ammonium ions react with the phenolic chromogen and hypocrite to give a green colored complex. The intensity of the color formed is measured at $578 \mathrm{~nm}$ and is directly proportional to the concentration of urea in test specimen [36].

Creatinine reacts with the picric acid in an alkaline medium to form an orange colored complex. The rate of formation of this complex is measured by reading the change in absorbance at $520 \mathrm{~nm}$ in a selected interval of time and is proportional to the concentration of creatinine. The reaction time and the concentration of picric acid and sodium hydroxide have been optimized to avoid interference from ketoacids [36].

\section{Statistical analysis}

The results are expressed in mean \pm standard deviation. Statistical analysis was performed using Students t-test. $\mathrm{p}<0.05$ was considered to be statistically significant.

\section{RESULTS}

Effect of $X$. pyrum on relative organ weights after cisplatin administration

Body weight of each animal was taken before sacrifice, lymphoid organs such as thymus and spleen were excised, weighed and expressed as relative organ weight and shown in Table 1 . The cisplatin treated animals showed a high reduction in the weight of all the organs such as $0.23 \pm 0.02 \mathrm{~g} / 100$ g body weight of spleen, $0.17 \pm 0.01 \mathrm{~g} / 100 \mathrm{~g}$ body weight of thymus, $3.7 \pm 0.19 \mathrm{~g} / 100 \mathrm{~g}$ body weight of liver, $1.2 \pm 0.01 \mathrm{~g} / 100 \mathrm{~g}$ body weight of kidney, and $0.62 \pm 0.01 \mathrm{~g} / 100 \mathrm{~g}$ body weight of lungs. The cisplatin treated along with $X$. pyrum mice showed a significant increase in the weight of all the organs such as $0.34 \pm 0.072 \mathrm{~g} / 100 \mathrm{~g}$ body weight of spleen, $0.23 \pm 0.01 \mathrm{~g} / 100 \mathrm{~g}$ body weight of thymus, $4.84 \pm 0.05 \mathrm{~g} / 100 \mathrm{~g}$ body weight of liver, $1.37 \pm 0.18 \mathrm{~g} / 100 \mathrm{~g}$ body weight of kidney, and $0.769 \pm 0.05 \mathrm{~g} / 100 \mathrm{~g}$ body weight of lungs. The $\mathrm{p}$ values of cisplatin-treated animals along with $X$. pyrum for spleen was $\mathrm{p}<0.01$, which was less significant but for thymus, liver, kidney and lungs it was $\mathrm{p}<0.05$ which was considered to be statistically significant. Weight of all relative organs was increased in cisplatin-treated animals by the extract administration, providing supportive evidence for $X$. pyrum extract is immune simulative.

Effect of $X$. pyrum on BMC and alpha-esterase activity after cisplatin administration

Bone marrow was collected from the femur into the medium containing $2 \%$ serum and made into single cell suspension.The number of cells was determined using a hemocytometer and expressed as total cells determined by trypan blue ( $1 \%$ in saline) exclusion method perfemur. Effect of X. pyrum on BMC and alpha esterase activity is given in Table 2 . The number of bone marrow cells, as well as alpha-esterase positive cells, was decreased drastically in cisplatin alone treated animals, but this was significantly $(\mathrm{p}<0.001)$ reversed by administration of $X$. pyrum. In cisplatin treated animals, on the $7^{\text {th }}$ day there was a drastic reduction in the number of bone marrow cells $\left(25.5 \times 10^{5} \pm 1.414\right.$ cells/femur $)$ and alpha-esterase positive cells $(634.5 \pm 3.05$ positive cells $/ 4000$ cells $)$ compared to $X$. pyrum treated along with cisplatin animals. Treatment with $X$. pyrum could elevate the BMC and number of alpha-esterase positive cells. In cisplatin-treated group of animals along with X. pyrum, $\mathrm{BMC}$ and alpha-esterase positive cells was found to be $68.30 \times 10^{5} \pm 4.24$ cells/femur and $1179 \pm 2.121$ cells/ 4000 bone marrow cells, respectively, on $7^{\text {th }}$ day and it was again enhanced to $69.7 \times 10^{5} \pm 4.24$ cells/femur and $1227 \pm 1.414$ cells $/ 4000$ bone marrow cells on $11^{\text {th }}$ day, respectively, compared to the cisplatin alone treated animals $\left(20.93 \times 10^{5} \pm 3.055\right.$ cells/femur and $620.66 \pm 3.05$ cells $/ 4000$ bone marrow cells).

\section{Effect of $X$. pyrum on enzyme levels after cisplatin administration SGOT}

An enzyme that is normally present in liver and heart cells. SGPT is released into the blood when the liver or heart is damaged. The blood SGPT levels are thus elevated. Also called AST a significant increase in the levels of SGOT $(82.280 \pm 2.7 \mathrm{IU} / \mathrm{L})$ and SGPT $(85.22 \pm 2.393 \mathrm{IU} / \mathrm{L})$ observed in the serum samples of cisplatin alone treated group was reversed by the administration of $X$. pyrum. Treatment with cisplatin along with $X$. pyrum significantly reduced the levels of SGOT $(52.68 \pm 0.46 \mathrm{IU} / \mathrm{L})$ and SGPT $(55.820 \pm 1.814 \mathrm{IU} / \mathrm{L})$ in serum, that is the $p$ value was found to be $p<0.001$ showing that the extract is highly significant.

\section{SGPT}

An enzyme that is normally present in liver and heart cells. SGPT is released into the blood when the liver or heart is damaged. The blood SGPT levels are thus elevated. Also called ALT cisplatin treated animals showed a decrease in the levels of SGOT $(32.67 \pm 2.7 \mathrm{IU} / \mathrm{L})$ and SGPT $(42.04 \pm 1.9 \mathrm{IU} / \mathrm{L})$ observed in the liver sample. Administration of $X$. pyrum significantly increased the level of SGOT $(41.545 \pm 1.3 \mathrm{IU} / \mathrm{L})$ and SGPT $(48.290 \pm 1.4 \mathrm{IU} / \mathrm{L})$ in the liver. The levels of SGOT and SGPT values are given in Tables 3 and 4. The SGPT level was increased drastically in cisplatin alone treated animals, but this was significantly

Table 1: Effect of $X$. pyrum on relative organ weights in cisplatin-treated animals

\begin{tabular}{|c|c|c|c|c|c|c|c|c|c|c|}
\hline \multirow[t]{3}{*}{ Treatment } & \multicolumn{10}{|c|}{ Relative organ weight (g/100 g body weight) } \\
\hline & \multicolumn{2}{|l|}{ Spleen } & \multicolumn{2}{|l|}{ Thymus } & \multicolumn{2}{|l|}{ Liver } & \multicolumn{2}{|l|}{ Kidney } & \multicolumn{2}{|l|}{ Lungs } \\
\hline & $7^{\text {th }}$ day & $11^{\text {th }}$ day & $7^{\text {th }}$ day & $11^{\text {th }}$ day & $7^{\text {th }}$ day & $11^{\text {th }}$ day & $7^{\text {th }}$ day & $11^{\text {th }}$ day & $7^{\text {th }}$ day & $11^{\text {th }}$ day \\
\hline Normal & $0.50 \pm 0.11$ & $0.69 \pm 0.02$ & $0.16 \pm 0.04$ & $0.18 \pm 0.02$ & $5.41 \pm 0.38$ & $5.98 \pm 0.39$ & $1.27 \pm 0.17$ & $1.26 \pm 0.22$ & $0.54 \pm 0.03$ & $0.59 \pm 0.02$ \\
\hline Cisplatin alone & $0.23 \pm 0.02$ & $0.20 \pm 0.04$ & $0.17 \pm 0.01$ & $0.15 \pm 0.07$ & $3.78 \pm 0.19$ & $3.60 \pm 0.40$ & $1.23 \pm 0.01$ & $0.98 \pm 0.04$ & $0.62 \pm 0.01$ & $0.53 \pm 0.03$ \\
\hline Cisplatin+X. pyrum & $0.34 \pm 0.07 * *$ & $0.41 \pm 0.14^{* *}$ & $0.23 \pm 0.01^{* *}$ & $0.26 \pm 0.04^{*}$ & $4.84 \pm 0.05^{*}$ & $5.58 \pm 0.30^{*}$ & $1.37 \pm 0.18^{*}$ & $1.43 \pm 0.08^{* *}$ & $0.76 \pm 0.05^{*}$ & $0.79 \pm 0.08^{*}$ \\
\hline
\end{tabular}

Values are expressed as mean \pm SD. 0.04<0.05; 0.001<0.01. X. pyrum: Xancus pyrum, SD: Standard deviation 
Table 2: Effect of $X$. pyrum on BMC and alpha-esterase activity in cisplatin-treated animals

\begin{tabular}{|c|c|c|c|c|}
\hline \multirow[t]{2}{*}{ Treatment } & \multicolumn{2}{|l|}{ BMC (cells/femur) } & \multicolumn{2}{|c|}{$\begin{array}{l}\text { Alpha-esterase activity (number of } \\
\text { alpha-esterase positive cells } / 4000 \text { cells) }\end{array}$} \\
\hline & $7^{\text {th }}$ day & $11^{\text {th }}$ day & $7^{\text {th }}$ day & $11^{\text {th }}$ day \\
\hline Cisplatin alone & $25.5 \times 10^{5} \pm 1.414$ & $20.9 \times 10^{5} \pm 3.055$ & $634.5 \pm 3.055$ & $620.66 \pm 3.055$ \\
\hline Cisplatin $+X$. pyrum & $68.30 \times 10^{5} \pm 4.242^{* * *}$ & $69.7 \times 10^{5} \pm 4.950^{* * *}$ & $1179 \pm 2.121^{* * *}$ & $1227 \pm 1.414^{* * *}$ \\
\hline
\end{tabular}

Values are expressed as mean \pm SD. $0.04<0.05 ; 0.001<0.01$. BMC: Bone marrow cellularity, X. pyrum: Xancus pyrum, SD: Standard deviation

Table 3: Effect of $X$. pyrum treatment on the serum, liver SGOT levels in cisplatin-treated animals

\begin{tabular}{|c|c|c|c|c|}
\hline \multirow[t]{2}{*}{ Group } & \multicolumn{2}{|l|}{ SGOT (IU/L) } & \multicolumn{2}{|c|}{ Liver GOT (IU/L) } \\
\hline & $7^{\text {th }}$ day & $11^{\text {th }}$ day & $7^{\text {th }}$ day & $11^{\text {th }}$ day \\
\hline Normal & $9.064 \pm 0.3$ & $9.172 \pm 0.1$ & $90.16 \pm 2.9$ & $97.41 \pm 2.1$ \\
\hline Cisplatin alone & $76.92 \pm 1.8$ & $82.28 \pm 2.7$ & $43.88 \pm 2.3$ & $32.67 \pm 2.7$ \\
\hline Cisplatin $+X$. pyrum & $55.93 \pm 0.1 * * *$ & $52.68 \pm 0.4^{* * *}$ & $39.85 \pm 0.7^{* *}$ & $41.54 \pm 1.3^{* *}$ \\
\hline
\end{tabular}

Values are expressed as mean \pm SD. $0.04<0.05 ; 0.001<0.01$. X. pyrum: Xancus pyrum, SD: Standard deviation, SGOT: Serum glutamic oxaloacetic transaminase, GOT: Glutamic-oxaloacetic transaminase

Table 4: Effect of $X$. pyrum treatment on the serum, liver SGPT levels in cisplatin-treated animals

\begin{tabular}{llll}
\hline Group & SGPT (IU/L) & Liver GPT (IU/L) \\
\cline { 2 - 3 } & $\mathbf{7}^{\text {th }}$ day & $\mathbf{1 1}^{\text {th }}$ day & $\mathbf{7}^{\text {th }}$ day \\
\hline Normal & $9.390 \pm 0.2$ & $9.290 \pm 0.04$ & $69.45 \pm 2.05$ \\
Cisplatin alone & $74.65 \pm 1.4$ & $85.22 \pm 2.3$ & $40.91 \pm 0.96$ \\
Cisplatin+X. pyrum & $58.22 \pm 0.3^{* *}$ & $55.82 \pm 1.8^{* * *}$ & $70.36 \pm 0.09$ \\
\hline
\end{tabular}

Values are expressed as mean \pm SD. 0.04<0.05; 0.001<0.01. X. pyrum: Xancus pyrum, SD: Standard deviation, SGPT: Serum glutamic pyruvic transaminase,

GPT: Glutamic pyruvic transaminase

$(\mathrm{p}<0.001)$ reversed by administration of $X$. pyrum extract.

Effect of $X$. pyrum on the biochemical parameters after cisplatin administration

The blood urea nitrogen (BUN) test is a measure of the amount of nitrogen in the blood in the form of urea, and a measurement of renal function. Urea is a substance secreted by the liver and removed from the blood by the kidneys. The renal functions can be estimated by biochemical parameters like BUN, and creatinine is given in Tables 5 and 6. Cisplatin administration in mice was found to increase the BUN concentration in serum on $7^{\text {th }}$ day $18.19 \pm 0.2 \mathrm{mg} / \mathrm{dL}$ and $11^{\text {th }}$ day $2.20 \pm 0.04 \mathrm{mg} / \mathrm{dL}$, but this was significantly reduced to $7.00 \pm 0.12 \mathrm{mg} / \mathrm{dL}$ on the $7^{\text {th }}$ day and $7.025 \pm 0.05 \mathrm{mg} / \mathrm{dL}$ on the $11^{\text {th }}$ day by the administration of $X$. pyrum extract. Similarly, urea concentration in serum of cisplatin alone treated animals was increased, that is on $7^{\text {th }}$ day $17.54 \pm 0.4 \mathrm{mg} / \mathrm{dL}$ and on $11^{\text {th }}$ day it was $19.71 \pm 0.09 \mathrm{mg} / \mathrm{dL}$ which was significantly reduced to $15.01 \pm 0.2 \mathrm{mg} / \mathrm{dL}$ on $7^{\text {th }}$ day and $15.04 \pm 0.12 \mathrm{mg} / \mathrm{dL}$ on $11^{\text {th }}$ day by the administration of $X$. pyrum extract. The urea level was increased drastically in serum of cisplatin alone treated animals, but this was significantly $(\mathrm{p}<0.001)$ reversed by administration of $X$. pyrum extract. Cisplatin-treated animals showed an increase in the level of creatinine $1.438 \pm 0.09 \mathrm{mg} / \mathrm{dL}$ on the $7^{\text {th }}$ day and $1.457 \pm 0.08 \mathrm{mg} / \mathrm{dL}$ on the $11^{\text {th }}$ day in serum which was reversed to $1.07 \pm 0.04 \mathrm{mg} / \mathrm{dL}$ on the $7^{\text {th }}$ day and $0.92 \pm 0.08 \mathrm{mg} / \mathrm{dL}$ on the $11^{\text {th }}$ day by the administration of $X$. pyrum extract. It was also found that $\mathrm{p}<0.001$ showing that the cisplatin-treated animals along with $X$. pyrum extract were statistically significant.

\section{DISCUSSION}

Cancer is one of the dreadful diseases of this century. Radiotherapy and chemotherapy play an important role in cancer treatment. Radiotherapy and chemotherapy are associated with the toxic effect. They kill not only the tumor cell but also normal cells. Both these effects are associated with suppression of immune system. Most of the synthetic chemotherapeutic agents available today are immunosuppressant, cytotoxic, and exert several side effect [37].

Modulation of the immune system by cytotoxic agents is emerging as a major area in pharmacology, especially in the case where undesired immune suppression is the result of therapy. A major drawback of current cancer therapeutic practices such as chemotherapy and radiation therapy is bone marrow suppression resulting in cytopenia and subsequent suppression of humoral and cellular as well as nonspecific and specific cellular responses [38].

Weight of all relative organs was also increased in cisplatin-treated animals by the extract administration, providing supportive evidence for $X$. pyrum extract immune stimulative potential during treatment of cisplatin. The effect of Biophytum sensitivum on the BMC and alpha-esterase positive cells after the administration of the methanolic extract of $B$. sensitivum showed a significant $(\mathrm{p}<0.001)$ enhancement in the BMC $\left(28.3 \times 10^{6}\right.$ cells/femur $)$ compared to the normal control $\left(17.3 \times 10^{6} \mathrm{cells} /\right.$ femur $)$ animals. Moreover, the number of alpha-esterase positive cells was also found to be increased significantly $(\mathrm{p}<0.001)$ in the B. sensitivum treated animals $(1421$ cells/4000 bone marrow cells) compared to the normal animals ( 905 cells/4000 bone marrow cells [39].

Similarly, the effect of X. pyrum on the BMC and alpha-esterase positive cells after the administration of the methanolic extract of $X$. pyrum showed a significant $(\mathrm{p}<0.001)$ enhancement in the BMC in cisplatintreated animals, there was a drastic reduction in the number of bone marrow cells $\left(25.5 \times 10^{5} \pm 1.414\right.$ cells/femur $)$ and alpha-esterase positive cells $(634.5 \pm 3.05$ positive cells $/ 4000$ cells $)$ compared to $X$. pyrum treated along with cisplatin animals. Treatment with $X$. pyrum could elevate the BMC and number of alpha-esterase positive cells. In cisplatin-treated group of animals along with $X$. pyrum, BMC, and alphaesterase positive cells was found to be $69.7 \times 10^{5} \pm 4.24$ cells/femur and $1227 \pm 1.414$ cells $/ 4000$ bone marrow cells. 
Table 5: Effect of $X$. pyrum treatment on the serum urea levels in cisplatin-treated animals

\begin{tabular}{|c|c|c|c|c|}
\hline \multirow[t]{3}{*}{ Group } & \multicolumn{4}{|c|}{ Serum $(\mathrm{mg} / \mathrm{dL})$} \\
\hline & \multicolumn{2}{|c|}{ Urea concentration $(\mathrm{mg} / \mathrm{dL})$} & \multicolumn{2}{|c|}{ BUN concentration $(\mathrm{mg} / \mathrm{dL})$} \\
\hline & $7^{\text {th }}$ day & $11^{\text {th }}$ day & $7^{\text {th }}$ day & $11^{\text {th }}$ day \\
\hline Normal & $28.41 \pm 1.1$ & $31.19 \pm 1.4$ & $13.26 \pm 0.5$ & $14.56 \pm 0.6$ \\
\hline Cisplatin alone & $17.54 \pm 0.4$ & $4.71 \pm 0.09$ & $8.19 \pm 0.20$ & $2.20 \pm 0.04$ \\
\hline Cisplatin $+X$. pyrum & $15.01 \pm 0.2^{* * *}$ & $15.04 \pm 0.12^{* * *}$ & $7.00 \pm 0.12^{* * *}$ & $7.02 \pm 0.05^{* * *}$ \\
\hline
\end{tabular}

Values are expressed as mean \pm SD. $0.04<0.05 ; 0.001<0.01$. X. pyrum: Xancus pyrum, SD: Standard deviation, BUN: Blood urea nitrogen

Table 6: Effect of $X$. pyrum treatment on the serum, liver creatinine levels in cisplatin-treated animals

\begin{tabular}{lll}
\hline Group & Serum $(\mathbf{m g} / \mathbf{d L})$ \\
\cline { 2 - 3 } & $\mathbf{7}^{\text {th }}$ day & $\mathbf{1 1}^{\text {th }}$ day \\
\hline Normal & $1.750 \pm 0.04$ & $1.880 \pm 0.04$ \\
Cisplatin alone & $1.438 \pm 0.09$ & $1.457 \pm 0.08$ \\
Cisplatin $+X$. pyrum & $1.075 \pm 0.04^{* * *}$ & $0.920 \pm 0.05^{* * *}$ \\
\hline
\end{tabular}

Values are expressed as mean \pm SD. ${ }^{*} \mathrm{p}<0.05,{ }^{* *} \mathrm{p}<0.01,{ }^{* * *} \mathrm{p}<0.001$

X. pyrum: Xancus pyrum, SD: Standard deviation

In this study, chemoprotective effect of X. pyrum an important edible gastropod was found in mice. Administration of X. pyrum was found to increase the number of bone marrow cells significantly indicating the extract could stimulate the hematopoietic system. Moreover, there was an increased presence of alpha-esterase positive bone marrow cells indicating the extract treatment could also enhance the differentiation of stem cells. The extract was found to stimulate the weight of spleen and thymus indicating that $X$. pyrum stimulated the production of immune cells. The increased SGOT and SGPT levels in the serum of cisplatin-treated mice can be attributed to the damaged structural integrity of the liver and kidney because these enzymes are located in cytoplasm and are released into circulation after cellular damage [40]. The present study showed that $X$. pyrum extract had decreased the SGOT and SGPT levels in the serum during the cisplatin treatment in mice.

The BUN test is a measure of the amount of nitrogen in the blood in the form of urea, and a measurement of renal function. Urea is a substance secreted by the liver and removed from the blood by the kidneys. The most common cause of an elevated BUN is poor kidney function. A greatly elevated BUN $(>60 \mathrm{mg} / \mathrm{dL})$ generally indicates a moderate-to-severe degree of renal failure. Impaired renal excretion of urea may be due to temporary conditions such as dehydration or shock or may be due to either acute or chronic disease of the kidneys themselves [41].

Cisplatin administration in mice was found to increase the BUN concentration in serum and liver on the $7^{\text {th }}$ day and $11^{\text {th }}$ day, but this was significantly reduced to by the administration of $X$. pyrum extract, thus it's clear that the poor kidney function was enhanced by the $X$. pyrum extract. Cyclophosphamide treated animals showed an increase in the level of creatinine $1.536 \pm 0.0603 \mathrm{mg} / \mathrm{dL}$ on $11^{\text {th }}$ day and $1.526 \pm 0.03 \mathrm{mg} / \mathrm{dL}$ on $15^{\text {th }}$ day in serum which was reversed to $1.17 \pm 0.08 \mathrm{mg} / \mathrm{dL}$ on $11^{\text {th }}$ day $11^{\text {th }} 0.87 \mathrm{mg} / \mathrm{dL}$ on $15^{\text {th }}$ day by the administration of Bauhinia tomentosa [42]. Similarly, cisplatin administration in mice was found to increase the level of creatinine $1.438 \pm 0.09 \mathrm{mg} / \mathrm{dL}$ on $7^{\text {th }}$ day and $1.457 \pm 0.08 \mathrm{mg} / \mathrm{dL}$ on the $11^{\text {th }}$ day in serum which was reversed to $1.07 \pm 0.04 \mathrm{mg} / \mathrm{dL}$ on $7^{\text {th }}$ day and $0.92 \pm 0.08 \mathrm{mg} / \mathrm{dL}$ on the $11^{\text {th }}$ day by the administration of $X$. pyrum extract. It is scientifically proven marine gastropod $-X$. pyrum is an edible gastropod which contains $8-10 \%$ of protein, $4-5 \%$ of carbohydrates $2-3 \%$ of minerals, and $1-2 \%$ of fat. This also contains omega three fatty acids [43]. In the past several decades, thousands of marine compounds with tremendous pharmacological activities have been isolated, and more than a dozen of them are in different stages of human clinical trials against various diseases $[44,45]$.

\section{CONCLUSION}

Cancer is one of the leading causes of death around the world; it is characterized by uncontrolled growth and spread of abnormal cells. If the spread is not controlled, it can result in death. Several factors, including location and how the cancerous cells appear under the microscope, determine how cancer is diagnosed. An effort is made to review marine gastropods as important bioactive compounds with reference to their presence, and chemical and biofunctional benefits, there has been a relatively little information on the impact of these gastropod on human health [46]. The potential beneficial effects of marine gastropod have been studied particularly in X. pyrum as they are major marine gastropod. It shows strong antioxidant activity which is attributed to quenching singlet oxygen and scavenging free radicals. The potential role of the gastropods as dietary anti-oxidants has been suggested to be one of the main mechanisms for their preventive effects against cancer and inflammatory diseases. The main objective of the present study was to access the chemoprotective activities of methanolic extract of X. pyrum in cisplatin-induced toxicity in mice and to identify the effect of $X$. pyrum on relative organ weight, BMC, alphaesterase activity, enzyme levels, and biochemical parameters after cisplatin administration.

Cisplatin and its metabolites can bind to DNA, causing damage that may result in chromosome breaks, micronucleus formation and cell death. Administration of $X$. pyrum extract in cisplatin-treated mice found to enhance the BMC and alpha-esterase positive cells, which were drastically reduced in cisplatin alone treated control animals suggests that cisplatin-induced myelosuppression was reversed or inhibited by $X$. pyrum extract administration possibly through its chemoprotective activity.

\section{REFERENCES}

1. Proksch P, Edrada RA, Ebel R. Drugs from the seas-current status and microbiological implications. Appl Microbiol Biotechnol 2002;59(2-3):125-34.

2. Mayer AM, Gustafson KR. Marine pharmacology in 2000: Antitumor and cytotoxic compounds. Int J Cancer 2003;105(3):291-9.

3. Garcia-Fernandez LF, Reyes F, Sanchez-Puelles JM. The marine pharmacy, new antitumoral compounds from the sea. Pharmaceut News 2002;9:495-501.

4. Haefner B. Drugs from the deep: Marine natural products as drug candidates. Drug Discov Today 2003;8(12):536-44.

5. Goodman LS, Wintrobe MM, Dameshek W, Goodman MJ, Gilman A, McLennan MT. Nitrogen mustard therapy. Lancet Oncol 2002;2(4):221-5

6. Girdhani S, Bhosle SM, Thulsidas SA, Kumar A, Mishra KP. Potential of radio sensitizing agents in cancer chemo-radiotherapy. J Cancer Res Ther 2005;1(3):129-31.

7. Prakash J, Gupta SK. Natural products for chemoprevention. Indian J Med Pediatr Oncol 2000;25(3):3-37

8. Bouchet P. New records and species of Abyssochrysos (Mollusca, Caenogastropoda). J Nat Hist 1991;25:305-13.

9. Vijayakumaran VR, Gopal R, Kathiroli S. Marine organisms in Indian medicines and their future prospects. Nat Prod Rad 2008;7(2):139-45.

10. Siddiqui UK, Ahmad M, Kazmi MA. Composition of fatty acids of a gastropod, Xancus pyrum. J Islam Acad Sci 1989;2(3):165-67.

11. Madhuri S, Pandey G. Some anticancer medicinal plants of foreign origin. Curr Sci 2009;96(6):6-25.

12. Bruce NA, Lois SG, Walter CW. The causes and prevention of cancer. Proc Natl Acad Sci U S A 1995;92(12):5258-65. 
13. Gralla RJ, Houlihan NG. Understanding and Managing Chemotherapy Side Effects. $2^{\text {nd }}$ ed. ???: Cancer Care; 2008. p. 1-16.

14. Dahanuhar SA, Kulkarni RA, Rege NN. Pharmacology of medicinal plants and natural products. Indian J Pharm 2000;32(4):81-118.

15. Pallabi S, Somvanshi VS, Rao TA. Health of the Coastal Marine Environment and Fisheries Development in India. In Vision on Indian fisheries of $21^{\text {st }}$ century 1998 . p. 276-87.

16. Nicolau KC, Hepworth D, King NP, Finlay MR. Chemistry biology and medicine of selected Tubulin polymerizing agents. Pure Appl Chem 1999;71:989-97.

17. Chen P, Huang WB, Wang KJ. Immuno modulation in the marine gastropod halitosis diverse color exposed to benzo(a)pyrene. Oceanogr Environ Sci 2003;7:132-144.

18. Akerkar AS. Synthesis of some phenacyl nicotinate as potential anticholesterol emic agent. Proc Natl Chemother Conf II 1976;2:46-59.

19. Moltedo S, Rashid S, Lodhi F, Ahmad M. Preliminary cardiovascular activity evaluation of capparidisine, a spermidinealkaloid from Capparis decidua. Pak J Pharmacol 2006;6:71-108.

20. Harvey GB. Testing of drugs inhibiting the formation of gastric ulcers. J Pharm Toxico Methods 1992;8:33.

21. Raphael TJ, Kutten G. Immunomodulatory activity of naturally occurring monoterpenes car one, limonene and perillic acid. J Immunopharmacol Immunotoxicol 2003;25(2):285-94.

22. Sporn MB, Dunop NM, Newton DL, Smith JM. Prevention of chemical carcinogenesis by Vitamin A and its synthetic analogs (retinoids). Proc Natl Semin Cancer Prev 1976;35:1332-8.

23. Akula A, Vishala C, Pitchaiah G. Immunomodulatory activity of nutraceutical formulation and its potentiation by self-fortification and cow urine distillate fortification methods. Int J Pharm Pharm Sci 2017;9(8):15-9.

24. Schwartzman G, Hayee-Memon A, Shameel KM. Phycochemical Studies on Gracilaria follifera (Gigartinales, Rhodophyta). Proceedings of the First National Conference on Biochemistry; 2003. p. 150

25. Bhunia NS, Thoms C, Schupp P. Biotechnological potential of marine sponges and their associated bacteria as producers of new pharmaceuticals (Part II). J Int Biotechnol Law 2007;2:257-64.

26. Kelland LR. Marine Biotechnology in the $21^{\text {st }}$ Century, Problems, Promise, and Products. Washington, D.C.: National Academy Press; 1996. p. 132.

27. Armstrong PB, Cossins AR, Crawford DL. Fish as models for environmental genomics. Nat Rev Genet 1999;6(4):324-40.

28. Anderson RS, Good RA, Peng J, Sheng X, El-Sayed KA, Dunbar DC, et al. Marine natural products as prototype agrochemical agents. J Agric Food Chem 1976;51(8):2246-50.

29. Datta U, Hembra ML, Roy S, Mukherje P. Natural biomolecules from marine Snail Telescopium telescopiumand structure of its sperm. Phylogenet Study 2003;59:142-58.

30. Abbott RT. The genus strombus in the Indo-pacific. J IndoPacific Mollusca 1960;1:33-146.

31. Sallie R, Tredger JM, William R. Drugs and the liver. Biopharm Drug 1991;12:251-9.

32. Devasagayam TP, Tilak JC, Boloor KK, Ghaskadbi SS, Lele RD. Free radicals and antioxidants in human health. Curr Status Future Prospects 2002;52:794-804

33. Alagarswami K. On pearl formation in the Venerid bivalve, Gafrarium tumidum. J Mar Biol Assoc India 1965;7(2):345-7.

34. Appukuttan KK. On Lithophaga diberus-bisculcata, a tilidborer causing damage to the commercially important gastropod shells. Indian J Fish 1976;23(1-2):194-200.

35. Feri J. Production of Basic Diagnostic Laboratory Reagents.8: Eastern Mediterranean Series:11 WHO Regional Publication; 1998. p. 40-4.

36. Toro G, Ackermann PG. Pratical Clinical Chemistry. $1^{\text {st }}$ ed. Boston: Little, Brown \&Company; 1975. p. 484.

37. Ayoola GA, Ipav SS, Sofidiya MO, Bello A, Coker H. Phytochemical screening and free radical scavenging activities of the fruits and leaves of Allanblackia floribunda Oliv. (Guttiferae). Int J Health 2008; $1: 87-93$.

38. Sredni B, Gal R, Cohen IJ, Dazard JE, Givol D, Gafter U. Drugs and their uses in clinical biology. J Altern Complement Med 1992;34:108.

39. Guruvayoorappan C, Kuttan G. Immunomodulatory and antitumor activity of Biophytumsensitivum extract. Asian Pac J Cancer Prev 2007;8:27-32.

40. Cragg GM, Grothaus PG, Newman DJ. Impact of natural products on developing new anti-Cancer Agents. Cancer Chemother 2009;4:98-102.

41. Barnard LA, Macintyre IG, Pierce JW. Possible environmental index in tropical reef corals. Nat 1974;252:219-20.

42. Badami S, Moorkoth S, Rai SR, Kannan E, Bhojra JS. Antioxidant activity of Caesalpinia sappan heart wood. Biol Pharmacol 2003;26(11):1534-7.

43. Greenwald RA. Animal model for evaluation of arthritic drugs. Methodol Exp Clin Pharmacol 1991;13:75.

44. Brown BE, Howard LS. Responses of Coelenterates to Trace Metals and Laboratory Evaluation. Proceedings of $5^{\text {th }}$ International Coral Reef Symposium Tahiti; 1985. p. 465-470.

45. Renitta RE, Kumar PA, Patterson J. Effectiveness of immersion treatments in reducing populations of Vibrio cholera on Gastropod meat. Proc Natl Semin Mar Biodivers Source Food Med $2003 ;: 72-75$

46. Ikawati Z, Sismindari S. Cytotoxicity against Tumor cell lines of ribosome-inactivating protein (RIP)-like protein isolated from Mirabilis Jalapa L. Malays J Pharm Sci 2006;4:1-11. 